\title{
Influence of Meteorology on Particulate Matter (PM) and Vice-Versa over Two Indian Metropolitan Cities
}

\author{
K. Rama Krishna, Gufran Beig* \\ Indian Institute of Tropical Meteorology, Pune, India \\ Email: *beig@tropmet.res.in
}

How to cite this paper: Krishna, K.R. and Beig, G. (2018) Influence of Meteorology on Particulate Matter (PM) and Vice-Versa over Two Indian Metropolitan Cities. Open Journal of Air Pollution, 7, 244-262. https://doi.org/10.4236/ojap.2018.73012

Received: April 13, 2018

Accepted: August 19, 2018

Published: August 22, 2018

Copyright $(0) 2018$ by authors and Scientific Research Publishing Inc. This work is licensed under the Creative Commons Attribution International License (CC BY 4.0).

http://creativecommons.org/licenses/by/4.0/

\begin{abstract}
This present study addresses the relationship between Particulate Matter (PM) and meteorological parameters over two metropolitan cities in India (Delhi and Pune) together with the Potential sources contribution function (PSCF) in order to understand the role of the transport on the variability of $\mathrm{PM}$ for a period of one year. To examine the variations of PM, over different time scales (diurnal and seasonal), at different observational locations, diurnal scales, are shown that maximum values of standard deviations (SD) are found in early hours of morning around 10AM, and later hours in the night over Delhi, however, the maximum values of SD are found in the morning hours around 8 to 10 AM over Pune. The relationship between PM and meteorological parameters is studied and explains a positive relationship between wind speed and planetary boundary layer height (PBLH), with a PM. Also, analyses on the Potential source contributions function (PSCF) over Delhi show that higher source contributions are observed during months of November, December and January over the region of Indo Gangetic Plain (IGP) plane north and Eastward of Delhi. Similarly, over Pune, most of the time, the source contribution in terms of pollution in Pune is coming from the south-east and eastern part of India, except in the winter season in the months of (December, January, and February). This analysis clearly suggests that the orography is played a pivotal role over the variations of PM over Pune.
\end{abstract}

\section{Keywords}

Particulate Matter, Meteorological Parameters, Potential Source Contribution Function (PSCF), Monsoon

\section{Introduction}

Over last several decades, environmental chemistry and climate are major issues 
due to the drastic change in the levels of particulate matters (PM) and gaseous components in the metropolitan cities of all over the world [1] [2]. PM is a heterogeneous and complex mixture of liquid and solid particle in the ambient air having different sizes like fine $\left(\mathrm{PM}_{2.5}\right)$ and coarse $\left(\mathrm{PM}_{10}\right)$ particles and their concentration influences air quality over urban areas. Their concentration also plays an important role in the atmosphere such as radiation budget, cloud, and precipitation formation, visibility, etc. [3] [4]. Additionally, PM affects the climate indirectly by acting as cloud condensation nuclei and thereby affecting cloud microphysical and radiative properties [5] [6]. Ambient particles with aerodynamic diameters $<2.5 \mu \mathrm{m}\left(\mathrm{PM}_{2.5}\right)$ are mainly responsible to the health hazards and earth radiation budget while $\mathrm{PM}_{10}$ (aerodynamic diameters $<10 \mu \mathrm{m}$ ) is mainly accountable to the visibility [7]. $\mathrm{PM}_{2.5}$ has been directly linked to various health issues leading to mortality and morbidity [8] [9] [10] [11] and other environmental concerns [12]. Based on the World Health Organization-WHO (2002) report, 800,000 deaths ( $1.4 \%$ of the global population) can be attributed to urban air pollution. The growth of cities in developing countries is the strongest affected by urban air pollution showing the highest burden of diseases including increased mortality [13] [14]. PMs are released into the atmosphere due to the anthropogenic and natural activities; high PM loads in the urban areas are produced by local activities [15]. The major sources of PMs are incomplete combustion of fossil fuels, mixed industrials emissions, especially coal, diesel, use of bio-fuel in cooking stoves, municipal waste burning, crop residue, and brick kilns activities. In addition to this, $\mathrm{PM}_{10}$ emits in the air from the construction activities, paved and unpaved road, and also dust storm activities. Weather parameters are major components which play a dominant role in distribution of ambient pollutants in the atmosphere and also it varies from day to day, location to location and season to season. For example, Wind Speed (WS) and direction are considered to be the important meteorological variables that play a vital role in the distribution of pollutants [16] [17]. In addition to local activities and meteorological conditions, the transport of air parcels from the distinct regions is one of the factors leading to the concentrations of PMs at the site [18] [19]. To understand the PMs characteristics and their emission signature, many studies have been carried out across the world [20] [21] [22]. Limited studies have been done over India region such as [23] in Ahmadabad, [23] in Chennai [17] [24], Udaipur [25], in Pune [26] and [27] in Delhi. Detailed investigations of $\mathrm{PM}_{2.5}$ and $\mathrm{PM}_{10}$ with weather parameters are still limited in India. Continuous measurements of PMs along with meteorological parameters were used to understand the pollution load, seasonal variability, climatology, and the source of apportionment and trajectory pathway of these air pollutants over Delhi and Pune. Back trajectory calculations were also performed to study the effects due to meteorology.

\section{Material and Method}

\subsection{Topography and General Meteorology}

Delhi is located at $\left(28.37^{\circ} \mathrm{N} ; 77.12^{\circ} \mathrm{E}, 216 \mathrm{~m}\right.$ above mean sea level-MSL) and 
covers $\sim 1500 \mathrm{~km}^{2}$ of the industrial area including the suburban towns of Ghaziabad, Noida Faridabad, and Gurgaon. According to 2011 census, Delhi is the second highest populous ( 11 million population) city in India, as well as it is one of the most polluted urban environments over the globe. Delhi climate is humid subtropical climate and hot semi-arid with high temperatures of $40^{\circ} \mathrm{C}$ $45^{\circ} \mathrm{C}$ in pre-monsoon (warm) season while lowest of $13^{\circ} \mathrm{C}-15^{\circ} \mathrm{C}$ during in winter period. The monsoon arrives at the end of June, along with an increase in humidity.

Pune is located at $\left(18.5^{\circ} \mathrm{N} ; 73.8^{\circ} \mathrm{E}\right)$ an altitude of about $550 \mathrm{~m}$ above the MSLs, it is situated in the western zone of the Deccan plateau and covers an area of $\sim 700 \mathrm{~km}^{2}$. It is one of the most rapidly developing cities in India in terms of industries as well as vehicular population and also urbanization [28]. Pune has a tropical wet and dry climate with average temperatures ranging between 20 to $33^{\circ} \mathrm{C}$ [29]. Number of vehicles over Delhi and Pune are increasing 2 to 3 times [29] [30] within a decade. By the year 2010, the vehicular count for Delhi is 57 lakh's and over Pune, 1000 vehicles per hour cross the signal [29]. The monitoring stations are placed at strategically selected locations by including different sectors with vehicular transport, industrial pollution, biomass burning, residential etc. More detailed information about the instrumentation, quality control of the data from the SAFAR network at different observational locations over Delhi and Pune (http://safar.tropmet.res.in/) are reported in [24].

\subsection{Experimental Techniques}

Continuous measurements of $\mathrm{PM}_{2.5}$ and $\mathrm{PM}_{10}$ with meteorological parameters were carried out from the System of Air Quality Forecasting and Research (SAFAR) network of the year of January-December, 2015. It consists of eight Air Quality Monitoring Stations (AQMS) and Automatic Weather Stations (AWS) set up across Delhi and Pune. $\mathrm{PM}_{2.5}$ and $\mathrm{PM}_{10}$ mass concentrations were observed using the Beta Attenuation Monitor (BAM-1020; Met One Instruments, Inc., USA). The BAM-1020 measures the mass concentrations of airborne particulate matters in $\left(\mu \mathrm{g} / \mathrm{m}^{3}\right)$ using the principle of beta ray attenuation. A small Carbon-14 $\left(14^{\mathrm{C}}\right)$ element provides a constant source of high energy electrons known as beta rays. The beta particles are detected and counted by a sensitive scintillation counter. Detailed information of BAM-1020 has been reported in a study by [19]. AWS was continuously operated and measures meteorological parameters, viz. wind speed, wind direction, temperature, relative humidity, etc., during the study period and the data were recorded at every 5 min interval and then binned at the one-hour interval after a quality check for further analysis and comparisons [31]. Planetary boundary layer height (PBLH) is taken from ERA-Interim reanalysis data.

\subsection{Methodology}

\section{Potential Source Contributory Function of PM2.5}


The potential source contribution function (PSCF) is used to calculate the possible source locations using back trajectories [32]. The air mass back trajectories for Delhi and Pune during the year 2015 were calculated using the Hybrid Single-Particle Lagrangian Integrated Trajectory-4 (HYSPLIT-4) and are shown in Figure 7 and Figure 8 respectively. The back trajectories started from each 00:00 (UTC) on every month of the year 2015 at $100 \mathrm{~m}$, which represent air masses from low altitudes. We calculated five days (120-h) back trajectories at 24 hourly based on HYSPLIT using National Centers for Environmental Prediction (NCEP) reanalysis data with a gridded resolution of $1^{\circ} \times 1^{\circ}$. The arrival heights of the trajectories were at the surface $(100 \mathrm{~m})$. To calculate the PSCF, the geographic region covered by the trajectories was divided into an array of $0.3^{\circ} \times$ $0.3^{\circ}$ grid cells with surface height and the $\mathrm{PM}_{2.5}$ concentration kept within a threshold limit $95 \%$.

\section{Results \& Discussion}

\subsection{Annual Distribution of $\mathrm{PM}_{10} \& \mathrm{PM}_{2.5}$ over Delhi and Pune}

The analysis was begun from the annual variations of PM at all the observational locations over Delhi and Pune. The higher values of $\mathrm{PM}_{10}$ were observed over Delhi as compared to Pune (it was the same case for $\mathrm{PM}_{2.5}$ ). All the stations over Delhi were having the same amount of PM in all the seasons with the higher values are found during the pre and post monsoon seasons, and the lower values are observed during the monsoon months due to the settling of pollutants by rainout and washout mechanism. And the same is the case for Pune with the higher values were found during the pre-monsoon and the lower is observed during the summer monsoon season (Figure 1). The annual mean mass concentration of $\mathrm{PM}_{2.5}$ and $\mathrm{PM}_{10}$ over Delhi were in the ranges of $27-796 \mu \mathrm{g} / \mathrm{m}^{3}$ and $9-600\left(\mu \mathrm{g} / \mathrm{m}^{3}\right)$, respectively. However, in Pune $\mathrm{PM}_{2.5}$ and $\mathrm{PM}_{10}$ were found in the ranges of $3-428\left(\mu \mathrm{g} / \mathrm{m}^{3}\right)$ and $1-180\left(\mu \mathrm{g} / \mathrm{m}^{3}\right)$, respectively in the year 2015 . The annual mean concentrations ( \pm standard deviations) of $\mathrm{PM}_{2.5}$ and $\mathrm{PM}_{10}$ for all air quality stations for Delhi and Pune are shown in Table 1 and Table 2, respectively. Mean values of $\mathrm{PM}_{10}$ are higher over C.V Raman location with the value of around $229.15\left(\mu \mathrm{g} / \mathrm{m}^{3}\right)$ while the lower is observed for IMD Aya Nagar in terms of the mean values. While the maximum and minimum values that shown in Table 1 is over IGI airport is reported as highest among all the stations as $796.67 \mu \mathrm{g} / \mathrm{m}^{3}$ whereas the lowest is $38.46 \mu \mathrm{g} / \mathrm{m}^{3}$. Among the other observational locations, IMD Ayanagar is second to IGI airport with maximum (minimum) of $\mathrm{PM}_{10}$ as $761.97(27.02) \mu \mathrm{g} / \mathrm{m}^{3}$.

On the other hand, IMD Lodhi road is recorded the maximum (minimum) values of $\mathrm{PM}_{10}$ with $644.25(42.85) \mu \mathrm{g} / \mathrm{m}^{3}$. On the overall statistics of $\mathrm{PM}_{10}$ has shown the higher variability in terms of their standard deviation with 89.31 $\mu \mathrm{g} / \mathrm{m}^{3}$ while the lower Standard Deviation (SD) is observed over IITM Delhi with the values of $72.06 \mu \mathrm{g} / \mathrm{m}^{3}$. On an average, all the stations over Delhi have the SD of more $90 \mathrm{ug} / \mathrm{m}^{3}$ except single station IMD Aya Nagar. Also, it is the 

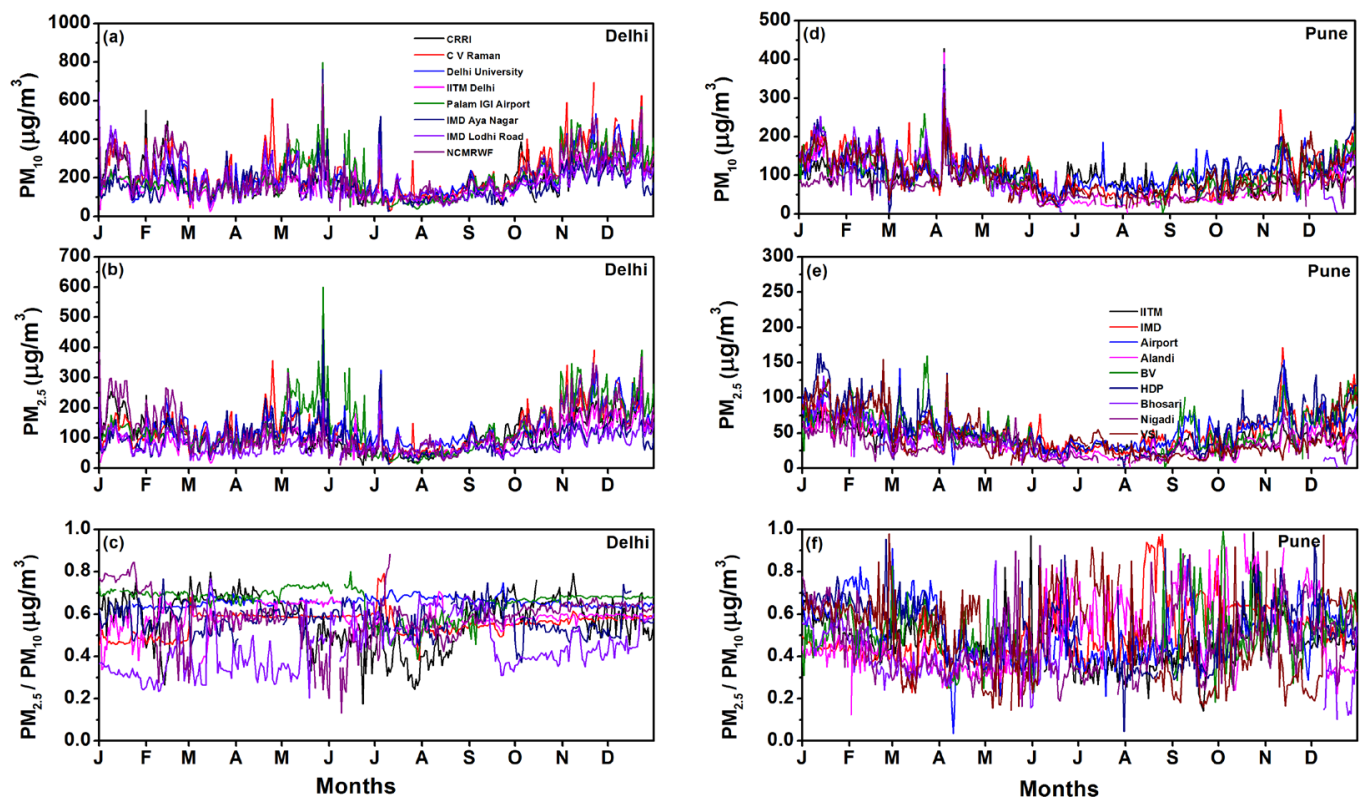

Figure 1. Annual variation of Particulate matter (a) $\mathrm{PM}_{10}$, (c) $\mathrm{PM}_{2.5}$ \& (e) $\mathrm{PM}_{2.5} / \mathrm{PM}_{10}$ over Delhi and (b) $\mathrm{PM}_{10}$, (d) $\mathrm{PM}_{2.5} \&$ (e) $\mathrm{PM}_{2.5} / \mathrm{PM}_{10}$ over Pune.

Table 1. Statically values for $\mathrm{PM}_{10}$ and $\mathrm{PM}_{2.5}$ for Delhi.

\begin{tabular}{ccccccccc}
\hline Site & Mean & Max & Min & Std & Mean & Max & Min & Std \\
\hline & PM $_{10}$ Concentration $\left(\mu \mathrm{g} / \mathrm{m}^{3}\right)$ & -2015 & $\mathbf{P M}_{2.5}$ Concentration $\left(\mu \mathrm{g} / \mathrm{m}^{3}\right)$ & -2015 \\
\hline CRRI & 91.76 & 683.41 & 53.73 & 95.29 & 110.36 & 430.65 & 9.37 & 57.46 \\
C V Raman & 229.15 & 711.03 & 28.01 & 115.61 & 127.38 & 412.93 & 17.91 & 65.56 \\
Delhi University & 209.80 & 662.05 & 66.16 & 97.53 & 136.16 & 421.06 & 46.78 & 60.25 \\
IITM Delhi & 165.08 & 526.41 & 25.51 & 72.06 & 96.64 & 318.35 & 16.91 & 44.95 \\
IGI Airport & 198.31 & 796.67 & 38.46 & 112.27 & 135.09 & 600.03 & 14.85 & 82.87 \\
IMD Aya Nagar & 164.69 & 761.97 & 27.02 & 78.70 & 93.85 & 459.98 & 13.65 & 46.30 \\
IMD Lodhi Road & 185.88 & 644.25 & 42.85 & 89.31 & 78.28 & 238.40 & 25.57 & 34.82 \\
\hline
\end{tabular}

Table 2. Statically values for $\mathrm{PM}_{10}$ and $\mathrm{PM}_{2.5}$ for Pune.

\begin{tabular}{|c|c|c|c|c|c|c|c|c|}
\hline Site & Mean & $\operatorname{Max}$ & Min & Std & Mean & $\operatorname{Max}$ & Min & Std \\
\hline & \multicolumn{4}{|c|}{$\mathrm{PM}_{10}$ Concentration $\left(\mu \mathrm{g} / \mathrm{m}^{3}\right)-2015$} & $\mathrm{PM}_{2.5}$ & \multicolumn{3}{|c|}{ Concentration $\left(\mu \mathrm{g} / \mathrm{m}^{3}\right)-2015$} \\
\hline IITM & 91.66 & 428.04 & 25.86 & 34.44 & 41.18 & 106.36 & 10.26 & 14.75 \\
\hline IMD & 105.99 & 386.53 & 16.66 & 50.62 & 51.82 & 171.30 & 8.43 & 23.19 \\
\hline Airport & 105.08 & 360.83 & 20.74 & 35.48 & 53.93 & 153.57 & 5.36 & 22.49 \\
\hline Alandi & 81.51 & 418.41 & 14.32 & 51.32 & 34.93 & 112.60 & 6.78 & 18.37 \\
\hline Katraj & 116.90 & 343.72 & 3.05 & 47.10 & 60.04 & 180.81 & 1.34 & 28.43 \\
\hline Bhosari & 117.12 & 333.39 & 4.34 & 58.98 & 46.93 & 131.07 & 1.05 & 25.68 \\
\hline Nigadi & 69.78 & 231.08 & 14.15 & 28.04 & 31.58 & 88.25 & 4.35 & 16.11 \\
\hline Manjri & 95.72 & 313.60 & 14.72 & 49.31 & 46.85 & 154.37 & 4.65 & 31.23 \\
\hline
\end{tabular}


same case for $\mathrm{PM}_{2.5}$ with the higher values of maximum values are recorded over IGI airport and IMD ayanagar with the minimum values of $14.85(13.65) \mu \mathrm{g} / \mathrm{m}^{3}$ with SD of $82.87(46.30) \mu \mathrm{g} / \mathrm{m}^{3}$ for the above two stations. From the statistical calculation, IMD Lodhi road recorded the lower values of both $\mathrm{PM}_{10}$ and $\mathrm{PM}_{2.5}$.

Both $\mathrm{PM}_{2.5}$ and $\mathrm{PM}_{10}$ concentrations are lower over Pune as compared to Delhi. Within Pune, overall results have shown the higher maximum values over IITM, Pune with Alandi is followed to IITM with the values of 428.04 for IITM and $418.41 \mu \mathrm{g} / \mathrm{m}^{3}$ for Alandi. Despite their maximum values, Alandi has shown higher variability of $51.32 \mu \mathrm{g} / \mathrm{m}^{3}$ than the IITM with a lesser value of about 34.44 $\mu \mathrm{g} / \mathrm{m}^{3}$. Further analysis infers the minimum values over Katraj (Bhosari) as 3.05 (4.34) $\mu \mathrm{g} / \mathrm{m}^{3}$ with higher SD values 47.10 (58.98). While it is the same case for the $\mathrm{PM}_{2.5}$ over these locations following the minimum values as 1.34 (1.05) $\mu \mathrm{g} / \mathrm{m}^{3}$ and higher SD as $28.43(25.68) \mu \mathrm{g} / \mathrm{m}^{3}$. Over Pune, Nigidi observational locations have recorded the lowest variability in both $\mathrm{PM}_{10}$ and $\mathrm{PM}_{2.5}$ among all the other nine stations. However, the overall variations of $\mathrm{PM}_{10}$ and $\mathrm{PM}_{2.5}$ over Pune is 2 and 3 times lesser than that of the Delhi respectively, and the annual mean mass concentration of $\mathrm{PM}_{10}$ and $\mathrm{PM}_{2.5}$ over Delhi is varied from 27.02 $\mu \mathrm{g} / \mathrm{m}^{3}$ to $796.67 \mu \mathrm{g} / \mathrm{m}^{3}$ and $9.37 \mu \mathrm{g} / \mathrm{m}^{3}$ to $600.03 \mu \mathrm{g} / \mathrm{m}^{3}$ respectively as well as in Pune the annual mean mass concentration of $\mathrm{PM}_{10}$ and $\mathrm{PM}_{2.5}$ is varied from 3.05 $\mu \mathrm{g} / \mathrm{m}^{3}$ to $428.04 \mu \mathrm{g} / \mathrm{m}^{3}$ and $1.05 \mu \mathrm{g} / \mathrm{m}^{3}$ to $180.81 \mu \mathrm{g} / \mathrm{m}^{3}$ as recorded in the year 2015. The observed values of $\mathrm{PM}_{10}$ and $\mathrm{PM}_{2.5}$ over Delhi have substantially exceeded the standards of their annual averages with reference to Indian National Ambient Air Quality Standards (NAAQS) i.e. $100 \mu \mathrm{g} / \mathrm{m}^{3}$ and $60 \mu \mathrm{g} / \mathrm{m}^{3}$ for 24 hours average. But over Pune observed values of $\mathrm{PM}_{10}$ and $\mathrm{PM}_{2.5}$ exceeds in winter and Pre-monsoon seasons only and rest of the period maintains the standard levels. According to previous studies over Delhi, the transport sector has contributed $45 \%$ to total $\mathrm{PM}_{2.5}$ concentrations, $27 \%$ of $\mathrm{PM}_{2.5}$ is contributed from industrial sector, $24 \%$ from industries and $4 \%$ from power sector [30] however, and major sources of overall air pollution in Delhi are: emissions from vehicles $(67 \%)$, coal-based thermal power plants (13\%), industrial units (12\%) and domestic exhaust (8\%) [4]. Figure 1 shows that the particulate matter levels are higher in the November and December followed by the May months over the Delhi, we can observe in the Pune the PM concentration is high during November and December followed by the April month.

\subsection{Diurnal Variations in $\mathbf{P M}_{10}$ and $\mathbf{P M}_{2.5}$}

The average diurnal variations in $\mathrm{PM}_{10}, \mathrm{PM}_{2.5}$ and their ratio concentration at Pune and Delhi are shown in Figure 2. Hourly averaged mean values as well as standard deviations for their variability are presented from the observational locations over both Delhi and Pune. Pronounced diurnal variations of PM are observed in both Metro cities, but with different daily patterns in the two cities. The variability over different locations over Delhi found to be higher in terms of their SD than the locations over Pune (Figure 2). The maximum values of SD 

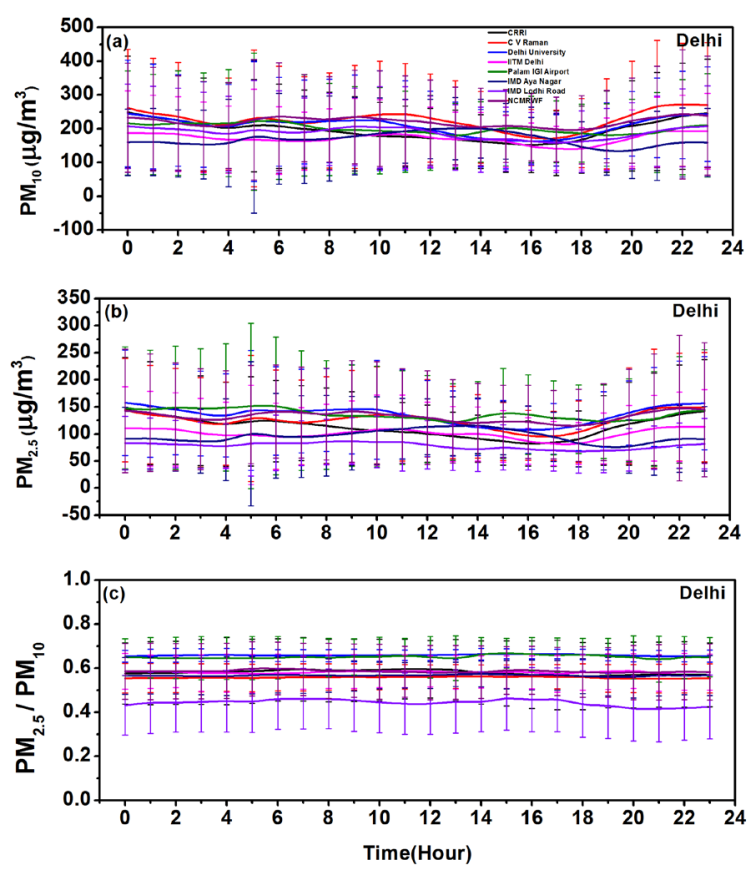
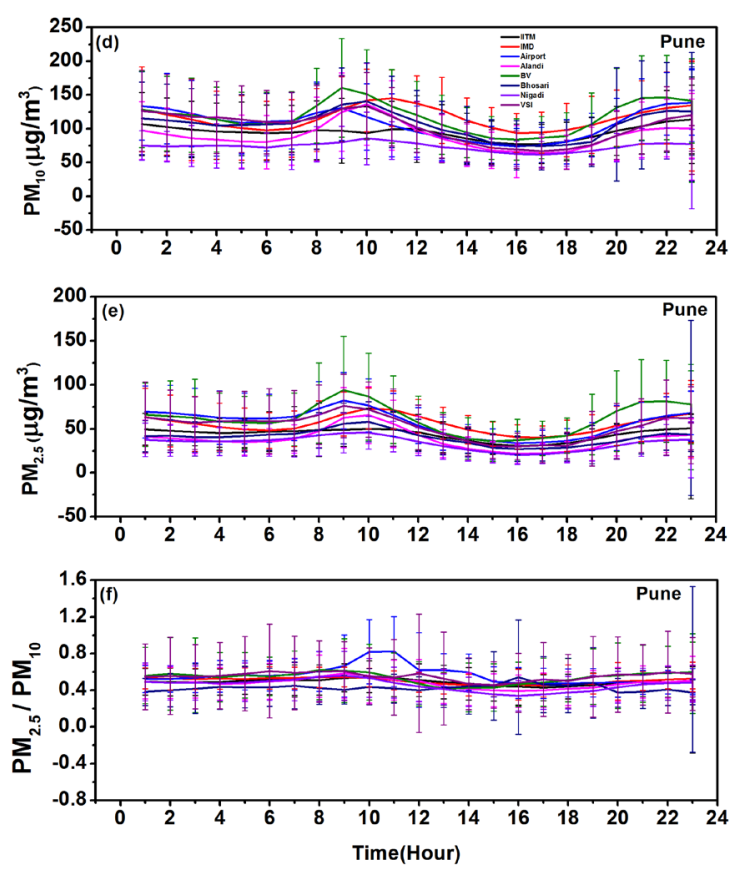

Figure 2. Diurnal Variation of Particulate matter (a) $\mathrm{PM}_{10}$, (c) $\mathrm{PM}_{2.5}$ \& (e) $\mathrm{PM}_{2.5} / \mathrm{PM}_{10}$ over Delhi and (b) $\mathrm{PM}_{10}$, (d) $\mathrm{PM}_{2.5}$ \& (e) $\mathrm{PM}_{2.5} / \mathrm{PM}_{10}$ over Pune.

was found in the early hours of the morning and later hours in the night over Delhi with also peak in the morning hours around $10 \mathrm{AM}$, on the other hand, the maximum values of SD are found in the morning hours around 8 to $10 \mathrm{am}$ over different locations over Pune. These higher deviations are mainly attributed due to the usage of a high number of vehicles which cause the higher emissions in the observed values. In the Metro area, $\mathrm{PM}_{2.5}$ concentrations are observed low at early morning hours to 8:00 am, followed by increase around 2:00 pm, and after which rises up to midnight 12:00 am. The metro area, therefore, displays a bimodal pattern with a weak signal. Whereas the Metropolitan cities are showing the strong bimodal pattern which is showing an almost similar pattern. The metro area has a dense traffic and huge pollution will lead to the high concentration of particulate matter as well as low diurnal variation. The morning peak is due to enhanced anthropogenic activity during rush hour. The condition is more or less same for both $\mathrm{PM}_{10}$ and $\mathrm{PM}_{2.5}$ with the less $\mathrm{SD}$ values over Pune as compared to Delhi. Interestingly the ratio of $\mathrm{PM}_{10}$ and $\mathrm{PM}_{2.5}$ has shown the higher values especially during the hours between 10 to $2 \mathrm{PM}$ whereas it is more is less similar pattern over Delhi with higher deviations.

Further, we have analyzed the diurnal variations of $\mathrm{PM}_{10}, \mathrm{PM}_{2.5}$ and their ratio patterns during different seasons are shown in Figure 3(a)-(f) over Delhi and Pune. The mean values of both the concentrations are calculated using different locations over both the metropolitan cities and presented for the discussion. PM concentrations show bimodal diurnal distribution during all the seasons. The diurnal cycle of $\mathrm{PM}_{10}$ is maximum in the midnight time around 12:00 AM with a 

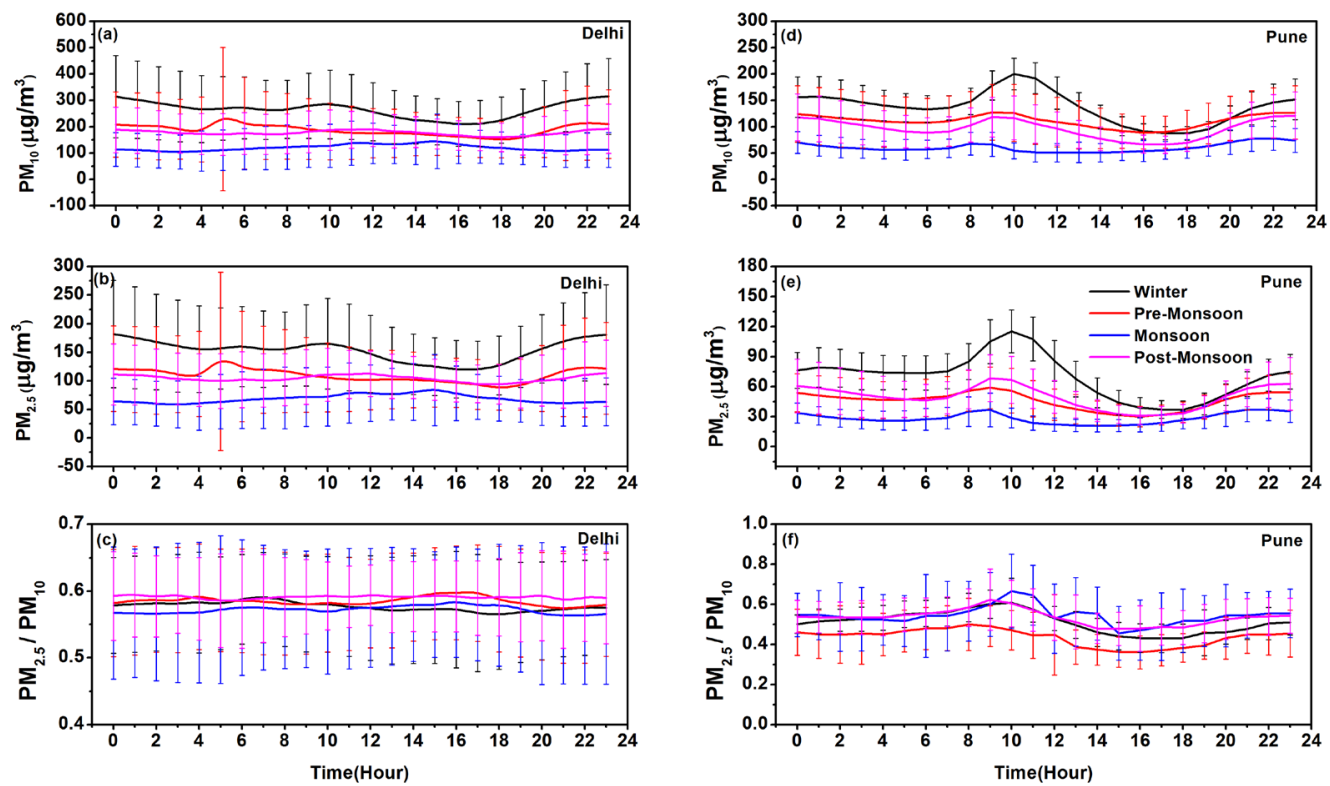

Figure 3. Diurnal variation of Particulate matter in different seasons (a) $\mathrm{PM}_{10}$, (c) $\mathrm{PM}_{2.5}$ \& (e) $\mathrm{PM}_{2.5} / \mathrm{PM}_{10}$ over Delhi and (b) $\mathrm{PM}_{10}$, (d) $\mathrm{PM}_{2.5}$ \& (e) $\mathrm{PM}_{2.5} / \mathrm{PM}_{10}$ over Pune.

value of around $285 \mu \mathrm{g} / \mathrm{m}^{3}$ during the winter season in Delhi while the minimum is observed around 16:00 PM with a value of $200 \mu \mathrm{g} / \mathrm{m}^{3}$, however, their high deviations are also observed around same time with $115 \mu \mathrm{g} / \mathrm{m}^{3}$ while the minimum is observed as $\sim 65 \mu \mathrm{g} / \mathrm{m}^{3}$. In case of Pune, it is observed that the maximum is around morning 10:00 AM with a value of about $200 \mu \mathrm{g} / \mathrm{m}^{3}$ and the minimum is same as Delhi at 16:00 PM with a value of $90 \mu \mathrm{g} / \mathrm{m}^{3}$. It is interesting to note that the variability is found to be higher during the midnight with a value around $40 \mu \mathrm{g} / \mathrm{m}^{3}$ while the minimum variability is observed in the afternoon hours with a value as low as $13 \mu \mathrm{g} / \mathrm{m}^{3}$. The mean and SD values over Pune are below the half of the values Delhi during the winter season. During the pre-monsoon season in the $\mathrm{PM}_{10}$, the concentrations shows maximum in the early hours of the morning around 5:00 PM which is about $230 \mu \mathrm{g} / \mathrm{m}^{3}$ while the minimum is observed around 18:00 PM with a value of $150 \mu \mathrm{g} / \mathrm{m}^{3}$ over Delhi. As it is mentioned, the higher variability is reported during the winter season, and pre-monsoon also follows the winter season, showing the same pattern of variability in terms of their SD, on the other hand, minimum variability is observed at 18:00 PM. But in the case of Pune, $\mathrm{PM}_{10}$ has shown two peaks in its diurnal time scale, one of the maximum is observed around 10:00 AM in the morning with a value of about $125 \mu \mathrm{g} / \mathrm{m}^{3}$ and the second peak is observed with the same magnitude at midnight 12:00 PM. Interestingly the diurnal scale of variability is more or less similar of a value of about approximately $50 \mathrm{ug} / \mathrm{mg}$ except for few hours between 14:00 PM to 20:00 PM with minimum variability. But it is clearly seen there is a diurnal variability in terms of their SD over Delhi that is observed with mean values showing two peaks with lesser amplitude difference between 10:00 AM to 16:00 PM during the summer monsoon season. Minimum values are ob- 
served during the early hours in the morning.

Higher SDs is observed in the morning hours while the lesser SDs is observed during the night hours over Delhi region in Figure 3(a) and Figure 3(b). Maximum (minimum) is found to be observed as $145(110) \mu \mathrm{g} / \mathrm{m}^{3}$ over Delhi which is the half of the magnitude compared to the winter season. The lower values during this season are attributed to the rain/washout mechanism which makes the values lesser in amplitude. One can clearly notice that there are two peaks in the $\mathrm{PM}_{10}$ over Pune during the monsoon season with a maximum observed during the late night around 11:00 PM with a value around $77 \mu \mathrm{g} / \mathrm{m}^{3}$ and the second maximum is found in the early hours of the morning with a value of $65 \mu \mathrm{g} / \mathrm{m}^{3}$. While the minimum is observed from 10:00 AM to 20:00 PM before start of a rise of its values in the diurnal cycle. This is may be the reason that the rain/washout mechanism is same as Delhi. It is also noticed that the values are lesser in both amplitude and as well as the standard deviations which are almost half of its values over Pune as compared to Delhi. After monsoon season completes, again the values of $\mathrm{PM}_{10}$ start rising and the same is seen in their diurnal cycle during the post-monsoon season over Delhi with the values more than 300 $\mu \mathrm{g} / \mathrm{m}^{3}$ during the late night and start to fall its values and it continues to reach a minimum of its value reaches $120 \mu \mathrm{g} / \mathrm{m}^{3}$ in the later afternoon. The variability also follows the mean values of maximum and minimum in timing. In the case of Pune, during the pre-monsoon, it follows same as like in the post-monsoon with two peaks one in the morning and other in the late night while the minimum is observed in the afternoon hours. Higher values of $\mathrm{PM}_{10}$ are observed during the post-monsoon season due to its settling and trapping of pollutants makes more health-related problems. The similar patterns are also observed for the $\mathrm{PM}_{2.5}$ during the different seasons over both Delhi and Pune. It also follows as like $\mathrm{PM}_{10}$ for the maximum and minimum values and their variability during different seasons, but with the weaker in the amplitudes. Similar patterns are evident in the ratio of both pollutants in the ratios of mean values and standard deviations.

\subsection{Role of Meteorology}

Ambient conditions of air pollution distribution will mainly depend on local meteorological conditions as well as long-range transport; Strong seasonality will lead to modulating the air quality levels [17] [27]. The seasonal distributions of ambient pollutants such as $\mathrm{PM}_{2.5}$ and $\mathrm{PM}_{10}$ are controlled by the emission sources, topography, local meteorology, transport factors and boundary layer height in the tropical atmosphere [19]. It is already well established that the meteorology will identify the transport and diffusion of the air pollution cycle, Meteorological factors such as winds direction, wind speed, temperature, precipitation, atmospheric boundary layer, relative humidity play an important role to determine the air pollution levels [33]. Impact of all these meteorological parameters in PM concentrations is significantly important and variability depends 
on the season or specific meteorological and atmospheric regimes dominated on certain days [34]. On the other hand, it is impossible to determine the influence of any individual meteorological parameter on PM concentrations with high accuracy due to contradictory and multiple effects that they may have on accumulation and dispersion of pollutants.

\subsubsection{Meteorology Influences on PM over Metro and Metropolitan City} Time series of particulate pollutants and meteorological variables are shown in Figure 4 and Figure 5. It shows annual variations of temperature, wind speed, relative humidity and planetary boundary layer, along with $\mathrm{PM}_{2.5}$ and $\mathrm{PM}_{10}$ concentrations on average of all the sites over Delhi and Pune during 2015. The level of $\mathrm{PM}_{10}$ crosses the threshold level in all months of the year except for the monsoon season (July-October) over Delhi region (Figure 4). The ambient air quality standard for $\mathrm{PM}_{10}$, set by India is $100 \mu \mathrm{g} / \mathrm{m}^{3}$ suggested by the World Health Organization (WHO) guidelines. The mass concentration of $\mathrm{PM}_{10}$ is found to be maximum during the months of March and December in almost all years [17] [33] [35]. Figure 4 shows the relationship between the PM and various meteorological parameters over Delhi. In Figure 4(a), the relationship with temperature has been plotted, it is shown that there are higher values of temperature during the lower values of PM, especially during the monsoon time, there is a reason behind the lower values of the PM values during monsoon period that is due to the rainout or washout mechanism, which causes to the settling of this pollutatnts due to the rainfall makes cleaner air with the lesser values [35]. Windblown dust is a major contributor in the pre-monsoon season to the higher concentrations of $\mathrm{PM}_{10}$ over Delhi. In Pune, $\mathrm{PM}_{10}$ was highest in March and April later on showing decreasing patterns even as PBL height also high. Low Planetary boundary layer height $(\mathrm{PBLH})$ indicates strong temperature inversion
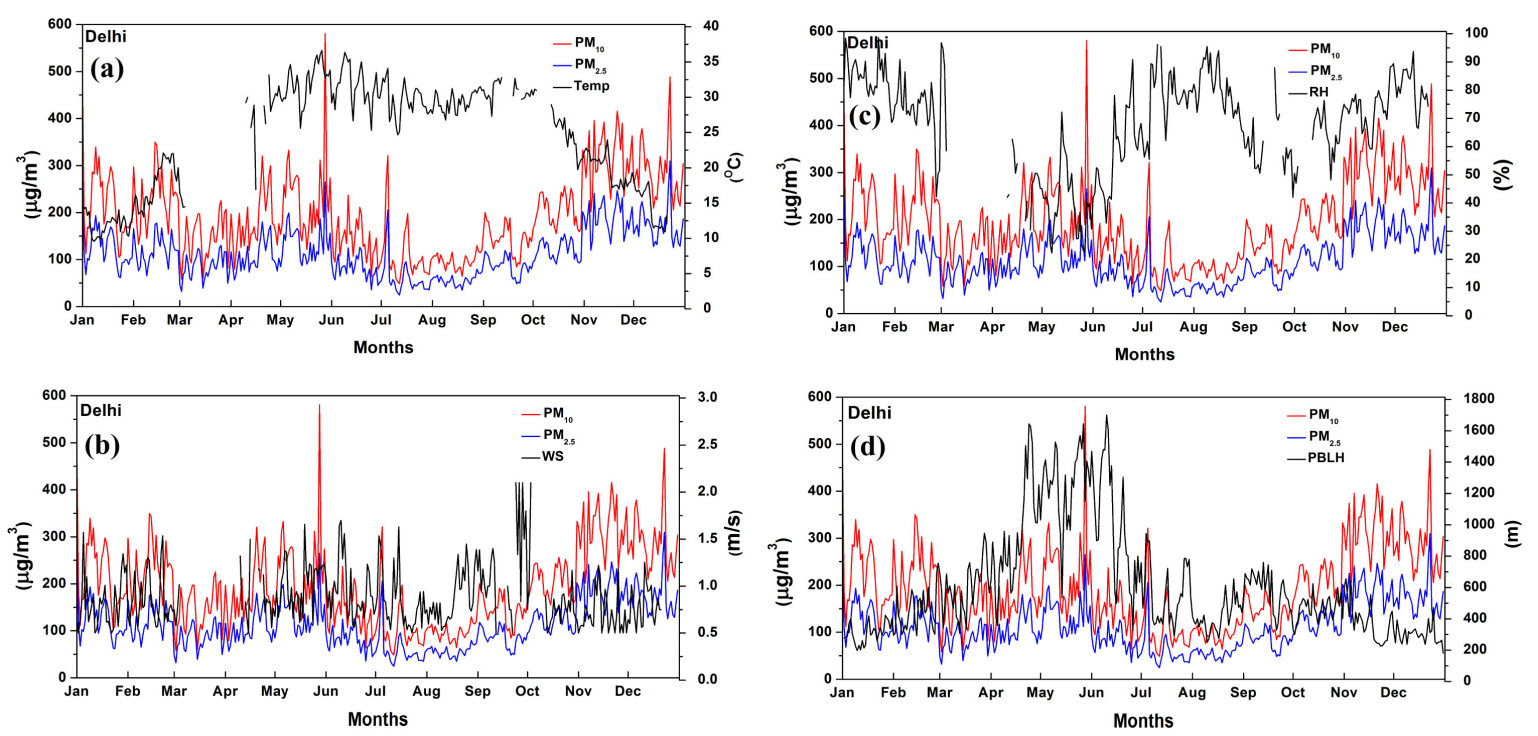

Figure 4. Annual variation of Particulate matter $\left(\mathrm{PM}_{10} \& \mathrm{PM}_{2.5}\right)$ with Temperature $\left({ }^{\circ} \mathrm{C}\right), \mathrm{RH}(\%)$, Wind Speed (m/s) and PBLH (m) over Delhi. 

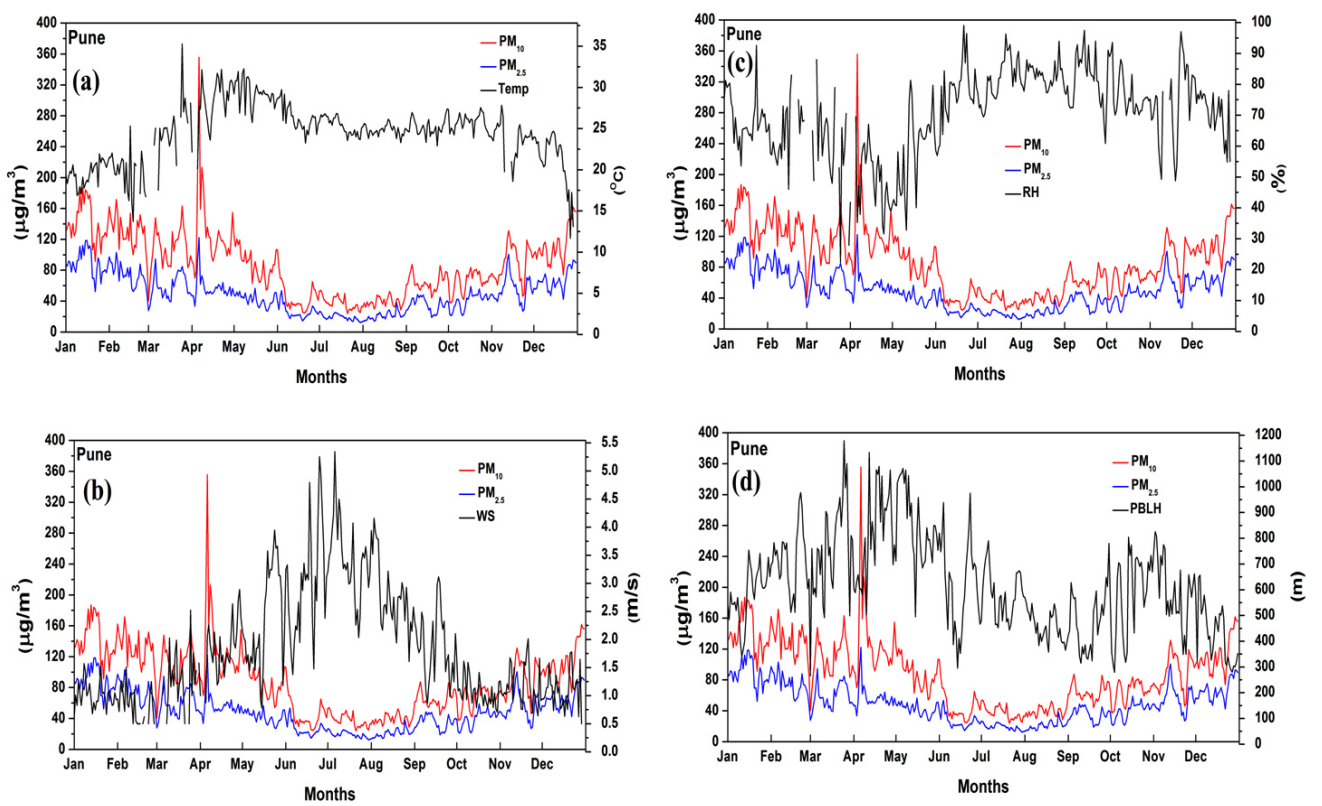

Figure 5. Annual variation of Particulate matter $\left(\mathrm{PM}_{10} \& \mathrm{PM}_{2.5}\right)$ with Temperature $\left({ }^{\circ} \mathrm{C}\right), \mathrm{RH}(\%)$, Wind Speed $(\mathrm{m} / \mathrm{s})$ and PBLH $(\mathrm{m})$ over Pune.

and downward air motion which favors the accumulation of $\mathrm{PM}_{2.5}$ and $\mathrm{PM}_{10}$ that emitted from local sources [36] [37]. $\mathrm{PM}_{10}$ particles are easily removed from the atmosphere due to the dry and wet deposition processes. Under high Relative Humidity-RH $\sim 90 \%$, low $\mathrm{PM}_{10}$ were due to well deposition of coarser particles. In Figure 4(b), its looks a negative relationship between RH and PM, when there are higher values especially during the monsoon. [33] Shows a similar kind of study show similar results over Delhi, PM is shown lesser. [18] Described the relation of RH and radiative properties of aerosols. [38] Has showed that the higher relative humidity and lower temperature during monsoon period at Pune caused the growth of cloud droplets which resulted in higher rainfall. Interestingly, a positive relationship has been found between wind speed and PM. It indicates that when there is higher value of winds causes the higher values of PM which is obvious reasons for a positive relationship. The same relationship also was observed for the planetary boundary height (PBLH).

On the other hand, the relationship between PM and meteorological parameters were further analyzed, as shown in Figure 5 over Pune. Figure 5(a), there are higher values observed during pre-monsoon and monsoon period in temperatures, but in case of PM, higher values only were observed during the pre-monsoon period. In case relative humidity throughout the year over Pune except during the pre-monsoon season, however, the minimum values of PM over Pune is also observed during the monsoon as like Delhi due to rainout/washout mechanism. However, a negative relationship is observed between wind speed and PM values especially during monsoon season, which is opposite to Delhi in Figure 5(c). One can clearly see there is a positive relationship between PBLH and PM over Pune. These relationships will provide with the dis- 
tinct meteorological systems which control the variability in different seasons over both metropolitan cities.

Further, in order to see the contribution from both $\mathrm{PM}_{10}$ and $\mathrm{PM}_{2.5}$, we have shown the scatter plot in Figure 6. It shows the linear relationship between $\mathrm{PM}_{10}$ and $\mathrm{PM}_{2.5}$, these parameters show higher positive correlations of about 0.94 (0.91) over Delhi (Pune). This analysis clearly indicates that these higher values of $\mathrm{CC}$ associated with the $\mathrm{PM}_{2.5}$ contribution in the particulate matter which causes the pollution over both the cities.

\subsubsection{Potential Source Contributions and Source Apportionment}

Long-range transport of particulate matter is important to understand the direct emissions from local sources. Figure 7 shows a panel plot of monthly PSCF from January to December 2015 at Delhi. Greater PSCF values indicate a higher contribution to $\mathrm{PM}_{2.5}$ concentration. An area corresponding to a grid of high PSCF value is a potential source region for $\mathrm{PM}_{2.5}$ concentration, and the trajectory through the region is a path indicating the high $\mathrm{PM}_{2.5}$ concentration. Most of the time the particle pollution is coming from the north-west and northern parts of India, except in the monsoon season (June, July, August, September) in which the particulate matter pollution is carried from the south-west and Arabian Sea part of India, It is because of carry forward of pollutants with mean winds during the monsoon. The values range from 0-1 showing a color from blue to red, and highest values of PSFC with a range of $(0.5-0.8)$ can be observed in the months of May in the northward portion of Delhi, as well in November, December and January was observed in the region of IGP plane north and Eastward of Delhi, It is due to the heavy dust loading in the pre-monsoon months and stagnant of winds in the winter months that causes the accumulation of pollutants in Delhi. The lowest PSFC values with a range of $(0.1-0.3)$ are observed in remaining months which appeared to be cleaner.

Figure 8 shows a panel plot of monthly PSCF form Jan-Dec 2015 at Pune, Most of the time the source of pollution in Pune is coming from the south-east and Eastern parts of India, except in the winter season (December, January, and February). Due to large temperature contrast of huge land and sea breeze circulation over the Indian region and the southern Indian Ocean, South West winds
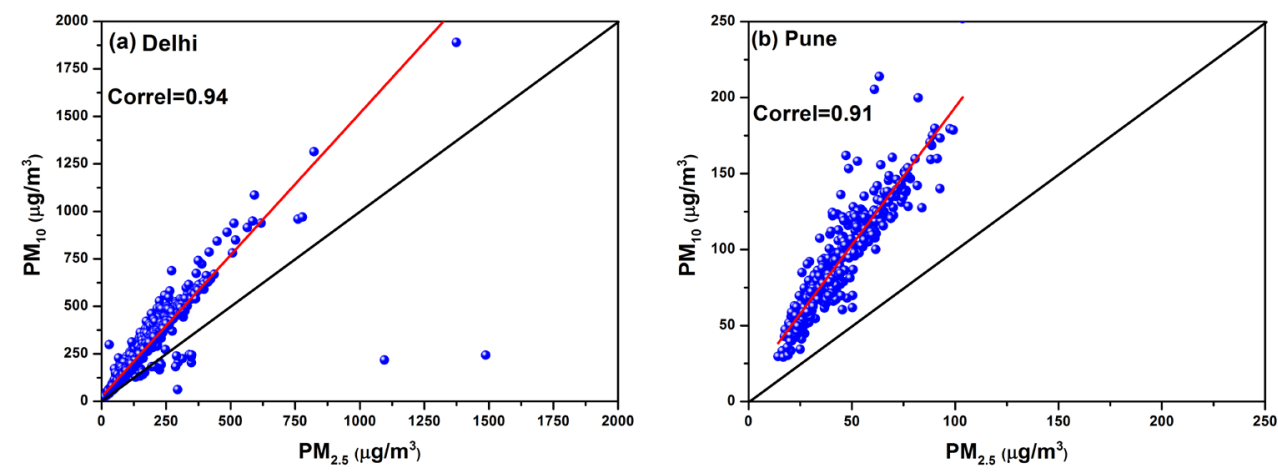

Figure 6. Correlation between $\mathrm{PM}_{10}$ and $\mathrm{PM}_{2.5}$ over Delhi \& Pune. 
(a) JAN

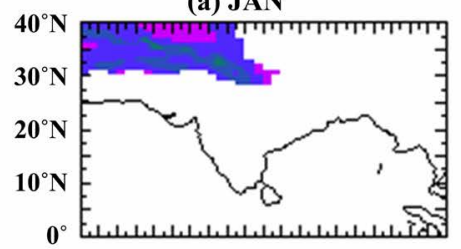

(d) APRIL

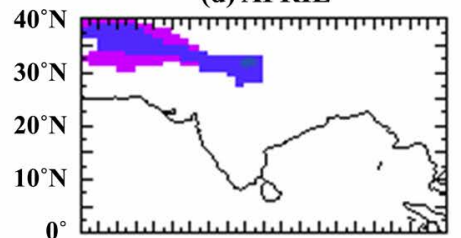

(g) JULY

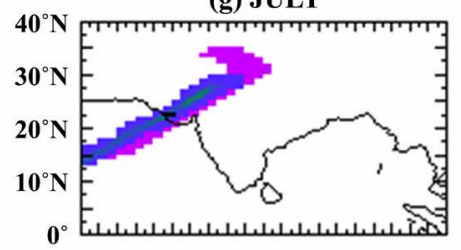

(j) OCTOBER

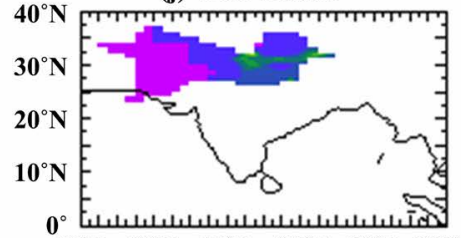

(a) FEB

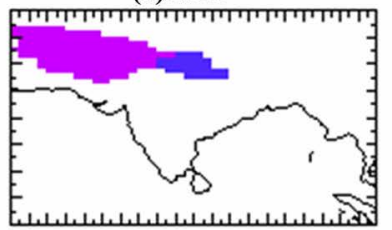

(e) MAY

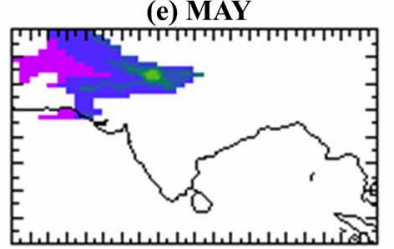

(h) AUGUST

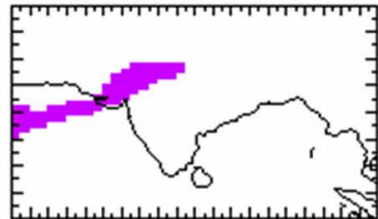

(k) NOVEMBER

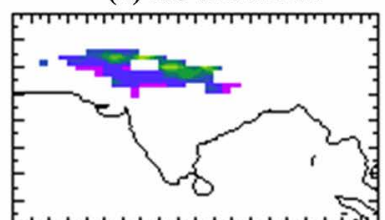

(c) MAR

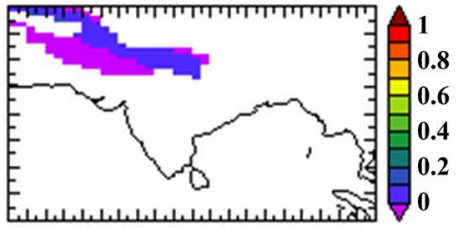

(f) JUNE

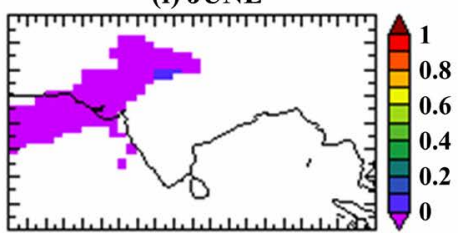

(i) SEPTEMBER

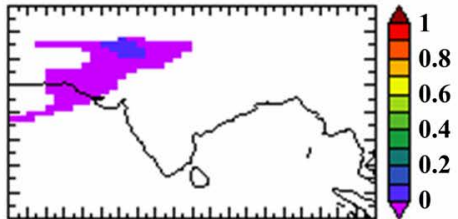

(I) DECEMBER

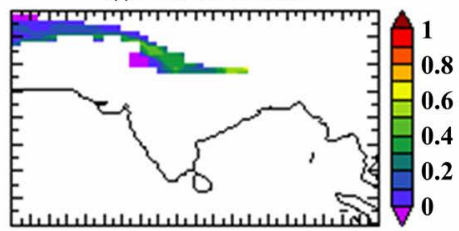

$60^{\circ} \mathrm{E} \quad 68^{\circ} \mathrm{E} \quad 76^{\circ} \mathrm{E} \quad 84^{\circ} \mathrm{E} \quad 92^{\circ} \mathrm{E} \quad 100^{\circ} \mathrm{E} 60^{\circ} \mathrm{E} \quad 68^{\circ} \mathrm{E} \quad 76^{\circ} \mathrm{E} \quad 84^{\circ} \mathrm{E} \quad 92^{\circ} \mathrm{E} \quad 100^{\circ} \mathrm{E} \quad 60^{\circ} \mathrm{E} \quad 68^{\circ} \mathrm{E} \quad 76^{\circ} \mathrm{E} \quad 84^{\circ} \mathrm{E} \quad 92^{\circ} \mathrm{E} 100^{\circ} \mathrm{E}$

Figure 7. Potential source contributory function of $\mathrm{PM}_{2.5}$ over Delhi.

(a) JAN

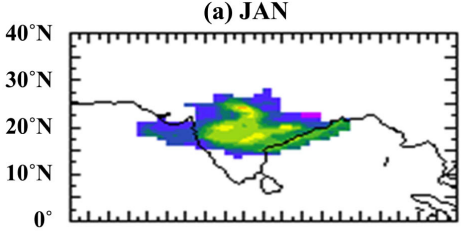

(d) APRIL

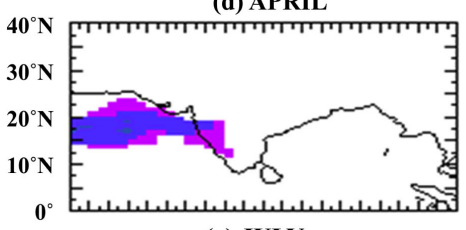

(g) JULY

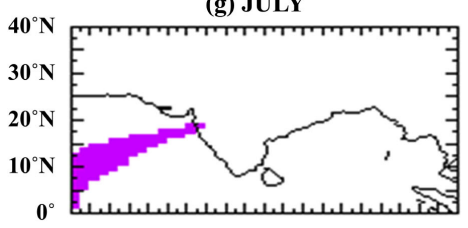

(j) OCTOBER

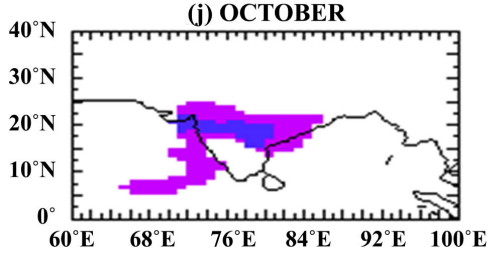

(a) FEB

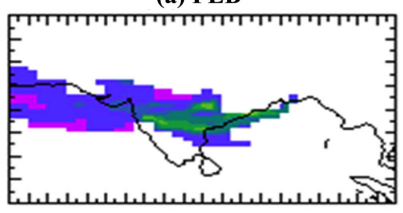

(e) MAY

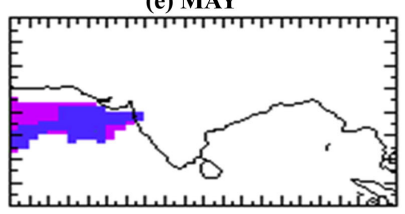

(h) AUGUST

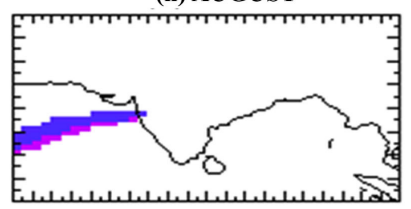

(k) NOVEMBER

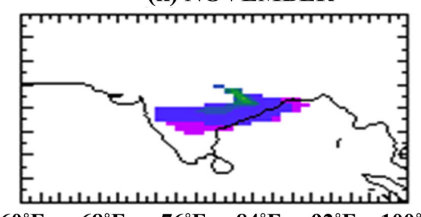

(c) MAR

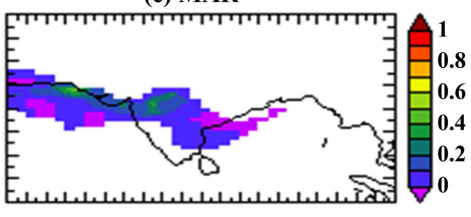

(f) JUNE

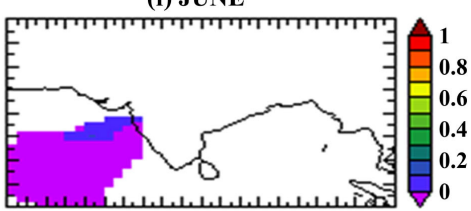

(i) SEPTEMBER

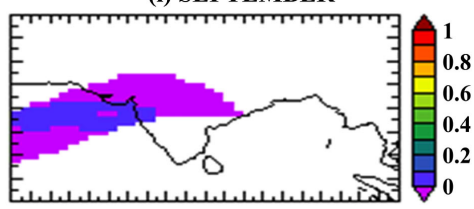

(I) DECEMBER

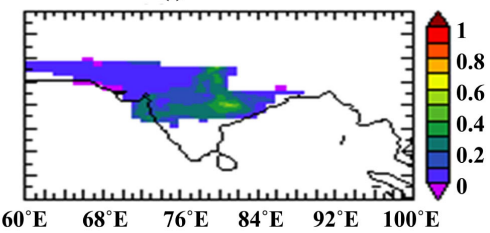

Figure 8. Potential source contributory function of $\mathrm{PM}_{2.5}$ over Pune. 
are carried out from the ocean with the strong winds called jet streams bring the particulate matter pollution toward the western ghat region of India, where Pune is located.

During the winter, temperatures are very low due to the topographical structure of the city, so planetary boundary is low and the winds are very calm. Hence in Pune, long-range transport occurs only in the Pre-monsoon and Monsoon periods, remaining Post Monsoon and Winter Periods are dominated by the local pollution events. As observed from Figure 8, values range from 0 - 1 showing a color from blue to red, and highest values of PSFC with a range of (0.5 - 0.9) can be observed in the months of January in the north-Eastern parts of Pune. The lowest PSFC values with a range of $(0.1-0.3)$ are observed in remaining months which appeared to be cleaner.

\section{Summary and Conclusions}

In this study the variability of PM over two metropolitan cities in India was studied using the ground-based observational datasets for the period of one year. In addition to this variability, we have also done the analysis on the source contributory function in order to understand the long-range transport of particulate matter; this will provide the information on the source regions from the emission points. Initially, we begin our analysis on variability by presenting the variations in diurnal and annual means along with their standard deviations. Analysis indicated that the higher values of $\mathrm{PM}_{10}$ are observed over Delhi as compared to Pune and also it is the same for $\mathrm{PM}_{2.5}$. Higher values were found during the pre and post monsoon with the lower values during the monsoon months due to settling of pollutants by rainout and washout mechanism at all the stations over Delhi. On the other hand, over Pune, higher concentrations are found during the pre-monsoon and lower values were observed during the summer monsoon season. The analysis is also based on different observational locations over Pune and Delhi by presenting the variations in terms of the means and standard deviations at all the observational locations. Overall analysis of the variations of $\mathrm{PM}_{10}$ and $\mathrm{PM}_{2.5}$ over Pune is 2 and 3 times lesser than the Delhi respectively and the annual mean mass concentration of $\mathrm{PM}_{10}$ and $\mathrm{PM}_{2.5}$ over Delhi is varied from $27-796\left(\mu \mathrm{g} / \mathrm{m}^{3}\right)$ and $9-600\left(\mu \mathrm{g} / \mathrm{m}^{3}\right)$, respectively. However, in Pune $\mathrm{PM}_{2.5}$ and $\mathrm{PM}_{10}$ were found in the ranges of $3-428\left(\mu \mathrm{g} / \mathrm{m}^{3}\right)$ and $1-180$ $\left(\mu \mathrm{g} / \mathrm{m}^{3}\right)$, respectively in the year 2015 . The variations at diurnal scales during the different seasons over both metropolitan cities over India also were studied by using the hourly values. The variability over different locations over Delhi was higher in terms of their SD than the locations over Pune. However, the maximum values of SD have found in the early hours of the morning and later hours in the night over Delhi with also peak in the morning hours around $10 \mathrm{AM}$, on the other hand, the maximum values of SD are found in the morning hours around 8 to 10 am over different locations over Pune. The reason for the higher concentrations of SD is mainly attributed due to the usage of a high number of 
vehicles which cause the higher during the observational period. In the diurnal cycle of $\mathrm{PM}_{10}$ is maximum in the midnight time around 12:00 AM with a value of around $285 \mu \mathrm{g} / \mathrm{m}^{3}$ during the winter in Delhi while the minimum is observed around 16:00 PM with a value of $200 \mu \mathrm{g} / \mathrm{m}^{3}$, however, their high deviations are also observed around same time with $115 \mu \mathrm{g} / \mathrm{m}^{3}$ while it is the minimum observed as $\sim 65 \mu \mathrm{g} / \mathrm{m}^{3}$. On the other hand, over Pune, it is observed that the maximum (minimum) is around in the morning 10:00 AM (at around 16:00 PM) with a value of about $200 \mu \mathrm{g} / \mathrm{m}^{3}\left(90 \mu \mathrm{g} / \mathrm{m}^{3}\right)$. The Metropolitan cities are showing the strong bimodal pattern which is showing an almost similar pattern. The metro area has a dense traffic and huge pollution will lead to the high concentration of particulate matter as well as low diurnal variation. Enhanced anthropogenic activities are a major source of the higher values in the diurnal. The condition is more or less same for both $\mathrm{PM}_{10}$ and $\mathrm{PM}_{2.5}$ with the less $\mathrm{SD}$ values over Pune as compared to Delhi. One interesting point here is to notice that the values are lesser in both amplitude and as well as the standard deviations which are almost half of its values over Pune as compared to Delhi.

Further, the relationship between the PM and meteorological parameters also were analyzed in order to see the roles on the maximum and minimum concentrations over both metropolitan cities. A positive relationship has been found $t$ between wind speed and PM. It indicates that when there is a higher value of winds causes the higher values of PM which is obvious reasons for a positive relationship and it is the same relationship for the case also for the planetary boundary layer height (PBLH). But it is interesting to note that there is a negative relationship is observed between wind speed and PM values especially during monsoon season over Pune, which is opposite to Delhi. This analysis will provide with the distinct meteorological systems which control the variability in different seasons at different time scales over both metropolitan cities.

In addition to above analysis, in order to see the long-range transport, $i$ the Potential source contributions function (PSCF) over both metropolitan cities also were analyzed. Higher source contributions were observed during the November, December, and January over the region of IGP plane north and Eastward of Delhi. This is mainly attributed to the heavy dust loading in the pre-monsoon months and stagnant of winds in the winter months the pollution accumulates in Delhi. The lowest values of PSCF within range of 0.1- 0.3 is observed in remaining all the months which appeared to be cleaner. On the other hand, over Pune, most of the time the source contribution in terms of pollution in Pune was coming from the south-east and Eastern part of India, except in the winter season in the months of (December, January, and February). Due to fact that the large temperature contrast, there are processes viz., land and sea breeze circulation over the Indian region and southern Indian Ocean, South West winds were carried out from the ocean with the strong winds called jet streams bring the particulate matter pollution toward the western ghats region of India, where Pune is located. This analysis clearly suggests that the orography is also 
played a pivotal over the variations of PM. And long-range transport occurs in the Pre-monsoon and monsoon periods, with remaining post-Monsoon and Winter Periods, are dominated by the local pollution events. This analysis is an insightful to understand the transport mechanism through the source contribution for the PM variations together with the aid of meteorological parameters over metropolitan cities. Long-term data sets further help to assess the variability at different time scales over different parts of India in order to understand the air quality standards and mitigation processes.

\section{Acknowledgements}

The authors are grateful to the Director, Indian Institute of Tropical Meteorology, Pune for their encouragement and support during the preparation of this manuscript. Authors also thank SAFAR and India Meteorological Department for data generation. Authors also thank HySPLIT to get the back trajectories data. Also authors would like to thank the anonymous reviewers for their valuable comments and suggestions to improve the quality of the paper.

\section{Conflicts of Interest}

The authors declare no conflicts of interest regarding the publication of this paper.

\section{References}

[1] Kumar, P., Khare, M., Harrison, R.M., Bloss, W.J., Lewis, A.C., Coe, H. and Morawska, L. (2015) New Directions: Air Pollution Challenges for Developing Megacities Like Delhi. Atmospheric Environment, 122, 657e661. https://doi.org/10.1016/j.atmosenv.2015.10.032

[2] Lawrence, M.G. and Lelieveld, J. (2010) Atmospheric Pollutant Outflow from Southern Asia: A Review. Atmospheric Chemistry and Physics, 10, 11017-11096. https://doi.org/10.5194/acp-10-11017-2010

[3] Ramanathan, V., Li, F., Ramana, M.V., Praveen, P.S., Kim, D., Corrigan, C.E., Nguyen, H., Stone, E.A., Schauer, J.J., Carmichael, G.R. and Adhikary, B. (2007) Atmospheric Brown Clouds: Hemispherical and Regional Variations in Long-Range Transport, Absorption, and Radiative Forcing. Journal of Geophysical Research: Atmospheres, 112. https://doi.org/10.1029/2006JD008124

[4] Stevens, B. and Feingold, G. (2009) Untangling Aerosol Effects on Clouds and Precipitation in a Buffered System. Nature, 461, 607-613.

https://doi.org/10.1038/nature08281

[5] Spracklen, D.V. and Rap, A. (2013) Natural Aerosol-Climate Feedbacks Suppressed by Anthropogenic Aerosol. Geophysical Research Letters, 40, 5316-5319. https://doi.org/10.1002/2013GL057966

[6] Twomey, S. (1977) The Influence of Pollution on the Shortwave Albedo of Clouds. Journal of the Atmospheric Sciences, 34, 1149-1152. https://doi.org/10.1175/1520-0469(1977)034<1149:TIOPOT>2.0.CO;2

[7] Seinfeld, J.H. and Pandis, S.N. (2006) Atmospheric Chemistry and Physics: From Air Pollution to Climate Change. 2nd Edition, John Wiley and Sons, Hoboken, NJ.

[8] Ghude, S.D., Chate, D.M., Jena, C., Beig, G., Kumar, R., Barth, M.C., Pfister, G.G., 
Fadnavis, S. and Pithani, P. (2016) Premature Mortality in India Due to PM2. 5 and Ozone Exposure. Geophysical Research Letters, 43, 4650-4658. https://doi.org/10.1002/2016GL068949

[9] Gurung, A. and Bell, M.L. (2012) Exposure to Airborne Particulate Matter in Kathmandu Valley, Nepal. Journal of Exposure Science and Environmental Epidemiology, 22, 235. https://doi.org/10.1038/jes.2012.14

[10] Valavanidis, A., Vlachogianni, T., Fiotakis, K. and Loridas, S. (2013) Pulmonary Oxidative Stress, Inflammation and Cancer: Respirable Particulate Matter, Fibrous Dusts and Ozone as Major Causes of Lung Carcinogenesis through Reactive Oxygen Species Mechanisms. International Journal of Environmental Research and Public Health, 10, 3886-3907. https://doi.org/10.3390/ijerph10093886

[11] Krishna, R.K., Ghude, S.D., Kumar, R., Beig, G., Kulkarni, R., Nivdange, S. and Chate, D. (2018) Surface PM2. 5 Estimate Using Satellite-Derived Aerosol Optical Depth over India. Aerosol and Air Quality Research, 18,

https://doi.org/10.4209/aaqr.2017.12.0568

[12] Jacobson, N.S., Martell, C.R. and Dimidjian, S. (2001) Behavioral Activation Treatment for Depression: Returning to Contextual Roots. Clinical Psychology: Science and Practice, 8, 255-270. https://doi.org/10.1093/clipsy.8.3.255

[13] Cohen, M.J., Carstenn, S. and Lane, C.R. (2004) Floristic Quality Indices for Biotic Assessment of Depressional Marsh Condition in Florida. Ecological Applications, 14, 784-794. https://doi.org/10.1890/02-5378

[14] McMichael, A.J. and Kovats, R.S. (2000) Global Environmental Changes and Health: Approaches to Assessing Risks. Ecosystem Health, 6, 59-66.

https://doi.org/10.1046/j.1526-0992.2000.00007.x

[15] Katsouyanni, K., Touloumi, G., Samoli, E., Gryparis, A., Le Tertre, A., Monopolis, Y., Rossi, G., Zmirou, D., Ballester, F., Boumghar, A. and Anderson, H.R. (2001) Confounding and Effect Modification in the Short-Term Effects of Ambient Particles on Total Mortality: Results from 29 European Cities within the APHEA2 Project. Epidemiology, 12, 521-531. https://doi.org/10.1097/00001648-200109000-00011

[16] Fleming, P.J., Allen, B.L. and Ballard, G.A. (2012) Seven Considerations about Dingoes as Biodiversity Engineers: The Socioecological Niches of Dogs in Australia. Australian Mammalogy, 34, 119-131. https://doi.org/10.1071/AM11012

[17] Yadav, R., Sahu, L.K., Jaaffrey, S.N.A. and Beig, G. (2014) Temporal Variation of Particulate Matter (PM) and Potential Sources at an Urban Site of Udaipur in Western India. Aerosol and Air Quality Research, 14, 1613-1629. https://doi.org/10.4209/aaqr.2013.10.0310

[18] Singh, A., Bloss, W.J. and Pope, F.D. (2017) 60 Years of UK Visibility Measurements: Impact of Meteorology and Atmospheric Pollutants on Visibility. Atmospheric Chemistry and Physics, 17, 2085-2101. https://doi.org/10.5194/acp-17-2085-2017

[19] Yadav, R., Sahu, L.K., Beig, G., Tripathi, N. and Jaaffrey, S.N.A. (2017) Ambient Particulate Matter and Carbon Monoxide at an Urban Site of India: Influence of Anthropogenic Emissions and Dust Storms. Environmental Pollution, 225, 291-303. https://doi.org/10.1016/j.envpol.2017.01.038

[20] Dubovik, O., Holben, B., Eck, T.F., Smirnov, A., Kaufman, Y.J., King, M.D., Tanré, D. and Slutsker, I. (2002) Variability of Absorption and Optical Properties of Key Aerosol Types Observed in Worldwide Locations. Journal of the Atmospheric Sciences, 59, 590-608. 
https://doi.org/10.1175/1520-0469(2002)059<0590:VOAAOP >2.0.CO;2

[21] El-Fadel, M. and Hashisho, Z. (2001) Vehicular Emissions in Roadway Tunnels: A Critical Review. Critical Reviews in Environmental Science and Technology, 31, 125-174. https://doi.org/10.1080/20016491089190

[22] Wallace, J.M. and Hobbs, P.V. (2006) Atmospheric Science: An Introductory Survey (Vol. 92). Academic Press, Cambridge.

[23] Bhaskar, B.V. and Mehta, V.M. (2010) Atmospheric Particulate Pollutants and Their Relationship with Meteorology in Ahmedabad. Aerosol and Air Quality Research, 10, 301-315. https://doi.org/10.4209/aaqr.2009.10.0069

[24] Kaushar, A., Chate, D., Beig, G., Srinivas, R., Parkhi, N., Satpute, T., Sahu, S., Ghude, S., Kulkarni, S., Surendran, D. and Trimbake, H. (2013) Spatio-Temporal Variation and Deposition of Fine and Coarse Particles during the Commonwealth Games in Delhi. Aerosol and Air Quality Research, 13, 748-755. https://doi.org/10.4209/aaqr.2012.02.0044

[25] Yadav, S., Praveen, O.D. and Satsangi, P.G. (2015) The Effect of Climate and Meteorological Changes on Particulate Matter in Pune, India. Environmental Monitoring and Assessment, 187, 402. https://doi.org/10.1007/s10661-015-4634-Z

[26] Parkhi, N., Chate, D., Ghude, S.D., Peshin, S., Mahajan, A., Srinivas, R., Surendran, D., Ali, K., Singh, S., Trimbake, H. and Beig, G. (2016) Large Inter Annual Variation in Air Quality during the Annual Festival “Diwali” in an Indian Megacity. Journal of Environmental Sciences, 43, 265-272. https://doi.org/10.1016/j.jes.2015.08.015

[27] Tiwari, S., Tiwari, S., Hopke, P.K., Attri, S.D., Soni, V.K. and Singh, A.K. (2016) Variability in Optical Properties of Atmospheric Aerosols and Their Frequency Distribution over a Mega City "New Delhi," India. Environmental Science and Pollution Research, 23, 8781-8793. https://doi.org/10.1007/s11356-016-6060-3

[28] Gawhane, R.D., Rao, P.S.P., Budhavant, K.B., Waghmare, V., Meshram, D.C. and Safai, P.D. (2017) Seasonal Variation of Chemical Composition and Source Apportionment of PM2.5 in Pune, India. Environmental Science and Pollution Research, 24, 21065-21072. https://doi.org/10.1007/s11356-017-9761-3

[29] Sahu, S.K., Beig, G. and Parkhi, N.S. (2011) Emissions Inventory of Anthropogenic PM2.5 and PM10 in Delhi during Commonwealth Games 2010. Atmospheric Environment, 45, 6180-6190. https://doi.org/10.1016/j.atmosenv.2011.08.014

[30] Sahu, S.K., Beig, G. and Parkhi, N. (2014) Critical Emissions from the Largest On-Road Transport Network in South Asia. Aerosol and Air Quality Research, 14, 135-144. https://doi.org/10.4209/aaqr.2013.04.0137

[31] Beig, G., Chate, D.M., Ghude, S.D., Mahajan, A.S., Srinivas, R., Ali, K., Sahu, S.K., Parkhi, N., Surendran, D. and Trimbake, H.R. (2013) Quantifying the Effect of Air Quality Control Measures during the 2010 Commonwealth Games at Delhi, India. Atmospheric Environment, 80, 455-463.

https://doi.org/10.1016/j.atmosenv.2013.08.012

[32] Draxler, R.R. and Hess, G.D. (1998) An Overview of the HYSPLIT_4 Modelling System for Trajectories. Australian Meteorological Magazine, 47, 295-308.

[33] Trivedi, D.K., Ali, K. and Beig, G. (2014) Impact of Meteorological Parameters on the Development of Fine and Coarse Particles over Delhi. Science of the Total Environment, 478, 175-183. https://doi.org/10.1016/j.scitotenv.2014.01.101

[34] Kishcha, P., da Silva, A.M., Starobinets, B. and Alpert, P. (2014) Air Pollution over the Ganges Basin and Northwest Bay of Bengal in the Early Post Monsoon Season Based on NASA MERRAero Data. Journal of Geophysical Research: Atmospheres, 
119, 1555-1570. https://doi.org/10.1002/2013JD020328

[35] Tiwari, S., Srivastava, A.K., Bisht, D.S., Parmita, P., Srivastava, M.K. and Attri, S.D. (2013) Diurnal and Seasonal Variations of Black Carbon and PM2.5 over New Delhi, India: Influence of Meteorology. Atmospheric Research, 125, 50-62. https://doi.org/10.1016/j.atmosres.2013.01.011

[36] Beig, G., Gunthe, S. and Jadhav, D.B. (2007) Simultaneous Measurements of Ozone and Its Precursors on a Diurnal Scale at a Semi Urban Site in India. Journal of Atmospheric Chemistry, 57, 239-253. https://doi.org/10.1007/s10874-007-9068-8

[37] Sahu, L.K., Yadav, R. and Pal, D. (2016) Source Identification of VOCs at an Urban Site of Western India: Effect of Marathon Events and Anthropogenic Emissions. Journal of Geophysical Research: Atmospheres, 121, 2416-2433. https://doi.org/10.1002/2015JD024454

[38] Devara, P.C.S., Raj, P.E., Gadgil, A.S., Patwardhan, B. and Tillu, A.D. (1998) Optical Network for Monitoring of Environmental Pollution. Journal of Optics (India), 27, 111-119. 